POLICY STATEMENT Organizational Principles to Guide and Define the Child Health Care System and/or Improve the Health of all Children

American Academy of Pediatrics

DEDICATED TO THE HEALTH OF ALL CHILDREN ${ }^{m}$

\title{
Cord Blood Banking for Potential Future Transplantation
}

William T. Shearer, MD, PhD, FAAP, ${ }^{a}$ Bertram H. Lubin, MD, FAAP, ${ }^{b}$ Mitchell S. Cairo, MD, FAAP, ${ }^{c}$

Luigi D. Notarangelo, MD, ${ }^{d}$ SECTION ON HEMATOLOGY/ONCOLOGY, SECTION ON ALLERGY AND IMMUNOLOGY

This policy statement is intended to provide information to guide pediatricians, obstetricians, and other medical specialists and health care providers in responding to parents' questions about cord blood donation and banking as well as the types (public versus private) and quality of cord blood banks. Cord blood is an excellent source of stem cells for hematopoietic stem cell transplantation in children with some fatal diseases. Cord blood transplantation offers another method of definitive therapy for infants, children, and adults with certain hematologic malignancies, hemoglobinopathies, severe forms of T-lymphocyte and other immunodeficiencies, and metabolic diseases. The development of universal screening for severe immunodeficiency assay in a growing number of states is likely to increase the number of cord blood transplants. Both public and private cord blood banks worldwide hold hundreds of thousands of cord blood units designated for the treatment of fatal or debilitating illnesses. The procurement, characterization, and cryopreservation of cord blood is free for families who choose public banking. However, the family cost for private banking is significant and not covered by insurance, and the unit may never be used. Quality-assessment reviews by several national and international accrediting bodies show private cord blood banks to be underused for treatment, less regulated for quality control, and more expensive for the family than public cord blood banks. There is an unquestionable need to study the use of cord blood banking to make new and important alternative means of reconstituting the hematopoietic blood system in patients with malignancies and blood disorders and possibly regenerating tissue systems in the future. Recommendations regarding appropriate ethical and operational standards (including informed consent policies, financial disclosures, and conflict-of-interest policies) are provided for physicians, institutions, and organizations that operate or have a relationship with cord blood banking programs. The information on all aspects of cord blood banking gathered in this policy statement will facilitate parental choice for public or private cord blood banking.

\section{abstract}

aDepartment of Pediatrics and Pathology and Immunology, College of Medicine, Baylor University and Section of Immunology, Allergy, and Rheumatology, Texas Children's Hospital, Houston, Texas; 'b Children's Health, University of California, San Francisco and Benioff Children's

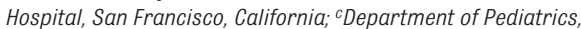
Medicine, Pathology, Microbiology and Immunology, and Cell Biology and Anatomy, Maria Fareri Children's Hospital and New York Medical College, Valhalla, New York; and ' Laboratory of Host Defenses, National Institute of Allergy and Infectious Diseases, National Institutes of Health, Bethesda, Maryland

All of the authors shared responsibility for writing and editing the document and reviewing and responding to questions and comments from reviewers and the Board of Directors.

This document is copyrighted and is property of the American Academy of Pediatrics and its Board of Directors. All authors have filed conflict of interest statements with the American Academy of Pediatrics. Any conflicts have been resolved through a process approved by the Board of Directors. The American Academy of Pediatrics has neither solicited nor accepted any commercial involvement in the development of the content of this publication.

Policy statements from the American Academy of Pediatrics benefit from expertise and resources of liaisons and internal (AAP) and external reviewers. However, policy statements from the American Academy of Pediatrics may not reflect the views of the liaisons or the organizations or government agencies that they represent.

The guidance in this statement does not indicate an exclusive course of treatment or serve as a standard of medical care. Variations, taking into account individual circumstances, may be appropriate.

All policy statements from the American Academy of Pediatrics automatically expire 5 years after publication unless reaffirmed, revised, or retired at or before that time.

DOI: https://doi.org/10.1542/peds.2017-2695

To cite: Shearer WT, Lubin BH, Cairo MS, et aIAAP SECTION ON HEMATOLOGY/ONCOLOGY, AAP SECTION ON ALLERGY AND IMMUNOLOGY. Cord Blood Banking for Potential Future Transplantation. Pediatrics. 2017;140(5):e20172695 


\section{INTRODUCTION}

Hematopoietic stem cells have the potential to reconstitute any blood cell type and rescue children with malignancies and other types of lifethreatening diseases. The need for cord blood transplantation to treat malignancies, hemoglobinopathies, primary immunodeficiencies, and metabolic diseases within the last decade ${ }^{1}$ has prompted the American Academy of Pediatrics (AAP) to revise its 2007 policy statement "Cord Blood Banking for Potential Future Transplantation." 2 This revised policy statement reviews the new applications for transplantation of the hematopoietic cells contained in cord blood taken from the placenta of normal newborn infants, blood that was previously discarded because of a lack of need for it. ${ }^{3}$ By 2013, more than 30000 hematopoietic stem cell transplants (HSCTs) have been performed by using cord blood as the source of stem cells worldwide. ${ }^{4,5}$ The disease distributions were $57 \%$ for malignancies, $32.5 \%$ for hemoglobinopathies, $6 \%$ for severe combined immunodeficiency disease (SCID) or related T-lymphocyte disorders, and $1.5 \%$ for other disorders 6,7 (Table 1). Approximately 800000 cord blood units are being stored in public cord blood banks, and more than 5000000 cord blood units are stored in private cord blood banks. ${ }^{8}$ The trajectory of increase in the number of cord blood units being transplanted in patients older than 16 years has progressively increased over the past decade (Fig 1). Clinical outcomes of both malignant and nonmalignant disorders are beginning to emerge in the literature, and it is certain that HLA barriers can be breached more easily with cord blood transplants compared with nonmatched marrow or peripheral blood HSCT transplants. ${ }^{9-15}$ Stem cell quantity limitations in cord blood may be addressed by laboratory expansion of hematopoietic stem cells to meet the increased use of cord blood in older children and adults, as was seen in 1 limited study (which requires confirmation in a larger study). ${ }^{3,15-17}$ The implementation of universal newborn screening by using dried blood on filter paper and the T-lymphocyte receptor excision circle assay in more than 3000000 newborn infants permitted the recognition of the true incidence of SCID requiring HSCT; it was found to be nearly double (ie, 1 in 58000 live births) previous estimates. ${ }^{18}$ This new development has prompted the search for a more convenient method of HSCT, a method that applies to the use of cord blood. However, other sources of hematopoietic stem cells (eg, haploidentical parent donors) may prove useful for patients with infections. ${ }^{19,20}$ Perhaps the most immediate challenge is that of educating medical personnel, parents, and the public about the increasing need and uses of cord blood banking.

In the following sections, several important features of public versus private cord blood banking are compared: (1) purpose; (2) quality control and accreditation; (3) cost and use of banked cord blood; (4) education of medical personnel, expectant parents, and the public; (5) summary; and (6) recommendations. A review of these components will enable parents and medical personnel to make informed decisions on public or private cord blood banking for patients.

\section{PUBLIC VERSUS PRIVATE CORD BLOOD BANKING: PURPOSE AND OPINIONS}

\section{Purpose}

The primary goal of this policy statement is to help physicians address the question of the value of cord blood banking in public or private cord blood banks. ${ }^{2}$ Parents who save their children's cord blood in private cord blood banks
TABLE 1 Diseases Treated by Umbilical Cord Blood Transplant by Using Either Sibling or Unrelated Donors

\begin{tabular}{|c|c|}
\hline Malignant Diseases & Nonmalignant Diseases \\
\hline $\begin{array}{l}\text { Acute lymphocytic } \\
\text { leukemia }\end{array}$ & Fanconi anemia \\
\hline $\begin{array}{l}\text { Acute myelocytic } \\
\text { leukemia }\end{array}$ & $\begin{array}{l}\text { Idiopathic aplastic } \\
\text { anemia }\end{array}$ \\
\hline $\begin{array}{l}\text { Juvenile chronic } \\
\text { myelogenous } \\
\text { leukemia }\end{array}$ & Thalassemia \\
\hline $\begin{array}{l}\text { Chronic } \\
\quad \text { myelogeneous } \\
\text { leukemia }\end{array}$ & Sickle cell anemia \\
\hline Neuroblastoma & $\begin{array}{l}\text { Amegakaryocytic } \\
\text { thrombocytopenia }\end{array}$ \\
\hline \multirow{12}{*}{$\begin{array}{l}\text { Myelodysplastic } \\
\text { syndrome }\end{array}$} & Kostman syndrome \\
\hline & $\begin{array}{l}\text { Blackfan-Diamond } \\
\text { syndrome }\end{array}$ \\
\hline & $\begin{array}{l}\text { Severe combined } \\
\text { immunodeficiency }\end{array}$ \\
\hline & $\begin{array}{l}\text { X-linked } \\
\text { lymphoproliferative } \\
\text { syndrome }\end{array}$ \\
\hline & $\begin{array}{l}\text { Wiskott-Aldrich } \\
\text { syndrome }\end{array}$ \\
\hline & Hurler syndrome \\
\hline & Hunter syndrome \\
\hline & Gunther disease \\
\hline & 0steopetrosis \\
\hline & $\begin{array}{l}\text { Globoid cell } \\
\text { leukodystrophy }\end{array}$ \\
\hline & Adrenoleukodystrophy \\
\hline & Lesch-Nyhan syndrome \\
\hline
\end{tabular}

Adapted from Cairo MS, Rocha V, Gluckman E, Hale G. Wagner J. Alternative allogenic donor sources for transplantation for childhood diseases: unrelated cord blood and haploidentical family donors [published correction appears in Biol Blood Marrow Transplant. 2008;14(11):1317-1318]. Biol Blood Marrow Transplant. 2008;14(1, suppl 1):44-53. Copyright @2008 American Society for Blood and Marrow Transplantation.

need to be aware that should their child develop leukemia, the child's stored cord blood already contains premalignant cells and cannot, therefore, be used to treat the child (autologous transplant). ${ }^{21,22}$ In that case, the cord blood from an unrelated child (an allogeneic transplant) is needed. When there is a known genetic defect in a family, there can be a need for directed cord blood that could be stored in a cord blood bank location (usually at a major medical institute) at which HLA typing could be performed before transplant. New developments in early clinical trial research for regenerative purposes 


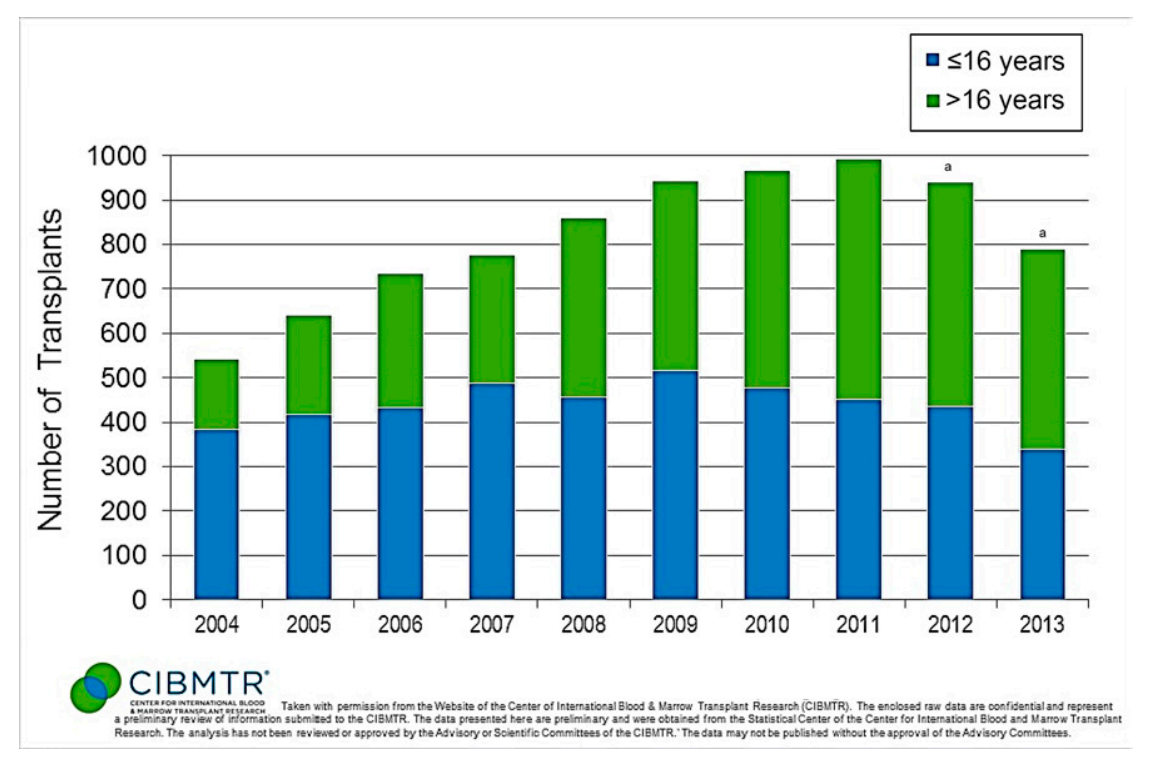

FIGURE 1

Umbilical cord blood transplant by age (based on unpublished data from the Center for International Blood and Marrow Transplant Research [CIBMTR] and reproduced with permission). Shown are the latest data available. ${ }^{\text {a }}$ Numbers for $2012-2013$ are lower because of a reporting lag.

may affect cord blood banking in the future. Some examples of these trials of cord blood transplants are those for Alzheimer disease, autism spectrum disorder, diabetes, cerebral palsy, hypoxic ischemic encephalopathy, systemic lupus erythematosus, and systemic sclerosis. ${ }^{4,5,23}$ However, no breakthrough in therapy has yet been realized.

\section{Worldwide Opinion on Public Versus Private Cord Blood Banking}

Since the publication of the previous AAP policy statement on cord blood banking, ${ }^{2}$ several other professional societies have issued similar statements. The American Society for Blood and Marrow Transplantation's view is that donation of cord blood to the public is preferable because the use of cord blood stored in private cord blood banks for therapy rarely occurs (ie, 1 in several 1000). ${ }^{3}$ The American Society for Blood and Marrow Transplantation acknowledges that private donation may be used for family members with nonmalignant conditions if there is good HLA matching between a donor and recipient.
Other professional groups that favor public cord blood bank donations over private cord blood banking include the International Federation of Gynecology and Obstetrics and the United Kingdom's Royal College of Obstetricians and Gynecologists. ${ }^{8}$ Petrini ${ }^{24}$ has addressed the critical issue of the ethics of private cord blood banking versus public cord blood banking. Most professional organizations support donation to public institutions. An exception to the preference of public cord blood banking would be in instances when a family member is identified as having a disease that can be cured by cord blood transplantation. In those instances, the use of family-directed cord blood banks (normally located within universities or, in some cases, nested in private cord blood banks) may be preferred. The review by Petrini ${ }^{24}$ lists all of the European and US professional organizations that strongly advocate for donation to and use of cord blood in public institutions: the Society of Obstetricians and Gynecologists of Canada, ${ }^{25}$ the
World Marrow Donor Association, ${ }^{26}$ the AAP, ${ }^{2}$ the American Congress of Obstetricians and Gynecologists, ${ }^{27}$ and the American Society for Blood and Marrow Transplantation. ${ }^{8}$

European countries have advocated for the adoption of strict guidelines regarding public collection and use of cord blood for transplant in the case of lifethreatening illnesses. ${ }^{28-39}$ The most expressive opinion of these position statements is from the Italian Committee for the Proper Use of Umbilical Cord Blood to the Chairman of the Health Commission of the European Parliament, which noted (1) the total absence of scientifically valid data proving that the therapeutic use of autologous cord blood stored for preventive purposes is appropriate, effective, and risk free; (2) the for-profit nature of the private collection and storage of umbilical cord blood; and (3) the contrast between this type of storage of cord blood and both the general interest and the principle of altruistic donations and solidarity repeatedly affirmed by the European Parliament. ${ }^{40}$ Canada and Australia, although favoring the promotion of public cord blood banking, nevertheless advocate for a cooperative relationship between public and private cord blood banks. ${ }^{41,42}$ Some attempts have been made to merge the concepts of public and private cord blood banking by holding private cord blood banks to the same level of excellence and regulation of laboratory experiments and storage facilities as public cord blood banks in preparation for allogeneic transplantation. ${ }^{43}$ One such hybrid cord blood bank has been evaluated and was found to be of less benefit to patients than either public or private cord blood banks separately. ${ }^{44}$ The authors concluded that continued emphasis should be placed on public cord blood banking. ${ }^{4}$ 


\section{QUALITY CONTROL AND ACCREDITATION OF CORD BLOOD BANKS}

As noted in the 2007 AAP policy statement, ${ }^{2}$ the emphasis on quality control and accreditation of cord blood banks is extremely important.$^{45}$ Several programs have such guidelines for accreditation, including NetCord and the Foundation for the Accreditation of Cellular Therapy (FACT), ${ }^{46}$ FACT and the Joint Accreditation Committee, ${ }^{47}$ and the American Association of Blood Banks. ${ }^{48}$ For example, their recommendations address the collection and storage of cord blood and prescribe the following: (1) cord blood receptacles, (2) time processing, (3) standard freezing and storage conditions, (4) segments of cord blood for testing and confirmation of identity, (5) extra cells for potential extra testing, (6) rapid testing for infectious agents, and (7) long-term storage of cord blood units in liquid nitrogen. ${ }^{36,40-48}$ These standards are critical for the safety of the prospective recipient and essential to physicians selecting products for use in HSCT. Only approximately $25 \%$ to $40 \%$ of collected umbilical cord blood units satisfy these criteria for storage in a public bank; in contrast, most private banks store the product regardless of cell count. ${ }^{49,50}$ Sun et $\mathrm{al}^{51}$ and others ${ }^{51-53}$ have compared the differences in quality between privately and publicly banked cord blood. The authors of these studies concluded that publicly stored cord blood was of a higher quality because private cord blood banks are not subject to the same regulatory oversight and have lesserquality stored cord blood units with decreased viability. ${ }^{51-53}$

\section{ACCESS, COST, AND USE OF BANKED CORD BLOOD}

\section{Access: Number of Cord Blood Banks in North America}

As of 2017, there are 28 public cord blood banks in North America (the United States, Canada, and Mexico; https://parentsguidecordblood. org/en/public-banking). These banks have sufficient capacity for those requesting a donation of cord blood. However, an area of concern is the relatively limited number of banked cord blood units that are HLA matched to patients belonging to ethnic and/or minority patients who need a cord blood transplant. More individuals from these groups need to store their infants' cord blood in cord blood banks. Education for ethnic and/or minority members of society is important to allow public cord blood banks to build their inventory to increase specific, HLAcompatible cord blood sets to serve the needs of all people.

\section{Cost}

There are no placement or maintenance fees for public cord blood banks. For private cord blood banks, a placement fee of $\$ 1350$ to $\$ 2300$ and an annual maintenance fee of $\$ 100$ to $\$ 175$ is required of families. ${ }^{54}$

\section{Use}

Ballen et $\mathrm{al}^{54}$ reported the results of 59 private cord blood banks surveyed for case reports of family cord blood units released for clinical use and compared these results to the World Marrow Donor Association data on public cord blood storage and release for clinical use.

These authors reported that 30 -fold more cord blood units stored in public cord blood banks have been released for clinical purposes as compared with those released from private cord blood banks. ${ }^{54}$

\section{EDUCATION: MEDICAL PERSONNEL, EXPECTANT PARENTS, AND THE PUBLIC}

\section{Need for Education About Cord Blood Banking}

In an AAP periodic survey of fellows, only $18 \%$ of pediatricians surveyed were somewhat familiar with the 2007 AAP policy regarding cord blood banking 1 year after its publication. ${ }^{55}$ This lack of awareness represents an opportunity to provide more education to physicians regarding the policy statement and information regarding cord blood banking. Using a survey tool with women in the third trimester of pregnancy or postpartum, Bhandari et $\mathrm{al}^{56}$ was able to show that the main reason women refuse donating the cord blood of their infants was a lack of information about the procedure and its outcome. Therefore, it is important that physicians become familiar with the advantages and disadvantages of public versus private cord blood banking to serve as a trusted resource to their patients. Educational opportunities on cord blood banking should be enhanced by educational seminars at national meetings and through electronic means of communication. The public has access to information through a variety of sources. Physicians can play a critical role in directing families to reliable sources of information on this topic. For example, additional information about cord blood banking is available through the Parent's Guide to Cord Blood Foundation (https:// parentsguidecordblood.org/en/ public-banking) and Be The Match (https://bethematch.org/About-us/). In addition, physicians have the opportunity to discuss key issues, including:

\section{Key Educational Points to Share With Parents}

When expectant parents are present during a medical office visit for their child or are establishing a relationship with the obstetrician or pediatrician before the child's birth, that physician and other health care providers may use that time as an opportunity to address the following:

- The rationale for public and private cord blood banking. Public cord 
blood banking serves the entire world, whereas private cord blood banking serves the needs of 1 family;

- The value of public cord blood banking to society. The parents of children who suffer fatal congenital disease or fatal acquired disease will be able to search the public cord blood banks throughout the United States and other countries as well for matching of cord blood stem cells with a patient's HLA antigens;

- Accreditation and regulatory oversight of public and private cord blood banking. Public cord blood banking is highly regulated by oversight accrediting institutions, whereas private cord blood banking may not meet the strict requirements of some accreditation bodies. Parents who are intent on donating their child's cord blood to a private cord blood bank are encouraged to ask industry representatives for evidence of validation and accreditation, financial cost, failure of cord blood to achieve successful engraftment, and backup electrical systems in case of storage equipment failure;

- Costs associated with public and private cord blood banking. There is no cost to families donating their infants' cord blood to public banks, whereas families who place their infants' cord blood with a private cord blood bank must pay a placement fee $(\$ 1350-\$ 2300)$ as well as a smaller annual maintenance fee $(\$ 100-\$ 175)^{54}$;

- The probability of use of public and private cord blood banking. The use rate of previously banked cord blood stem cells is at least 30 -fold greater in public cord blood banks compared with that of private cord blood banks ${ }^{54}$; and
- Informed consent and the decision time frame, financial disclosure, and conflict of interest. The optimal time to obtain informed consent and to make a decision on which form of cord blood banking (public or private) is at the first prenatal visit when the obstetrician and/ or pediatrician or other medical personnel can discuss the option in an unhurried environment. Parents should not be asked to make a decision after labor has begun. Disclosure of any medical personnel with conflicts of interest in cord blood collection should be made to the expectant family at this time. In addition, a declaration of potential conflict of interest needs to be made to the institution in which the collection of cord blood cells is to be made.

\section{CONCLUSIONS}

\section{Selection Criteria}

The AAP policy statement on cord blood banking for future transplantation has been revised because of the rapidly expanding need for cord blood for HSCT for patients with childhood malignancies, hemoglobinopathies, primary immunodeficiencies, metabolic disease, and other disorders. Because of the evolving use of cord blood transplants for new applications in medicine, there is an important need to inform medical personnel, parents, and the public alike about advances in therapeutic approaches for cellular immune reconstitution.

The number of cord blood transplants for primary immunodeficiency is expected to increase because SCID is increasingly being added to newborn screening programs in more and more states. Although this number of cord blood transplants is small compared with total HSCTs, such as bone marrow and peripheral blood stem cell transplants (ie, $>600000$ ), appreciation for alternative features and advantages of cord blood transplants, such as the use of partially HLA-matched donor stem cells over haploidentical stem cells, has not been fully evaluated.

External oversight of cord blood banking systems is critical in monitoring the quality of the blood product from collection to longterm storage. External agencies (such as FACT, which has developed accreditation guidelines and monitors public cord blood banks) serve as an important mechanism to ensure across-the-board conformity with the strict purity of product due to or expected by patients in need of cord blood transplants. It is important that similar mechanisms be implemented to monitor private cord blood banks.

As of today, public and private cord blood banking systems serve different purposes. Private cord blood banks serve parents who elect to store their children's cord blood for potential self-use later in life, although to date, there is little evidence supporting use for this purpose. Private cord blood banks also store cord blood for use in families with an identified sibling in need of a transplant or a genetic risk of producing a sibling with a transplantable disease. Public cord blood banks store donated blood for non-self-use (allogeneic) by individuals in the general public. On average, cord blood stored in private cord blood banks is (1) underused, (2) not subject to strict regulatory oversight, (3) expensive for the family, and (4) and may be of lesser quality (in number and quality of stem cells) than that stored in public cord blood banks. In contrast, cord blood donated to public banks is more commonly used and heavily regulated. Thus, the cost and value 
of the maintenance of private cord blood banks is not supported by the evidence for use at the present time. ${ }^{5}$

\section{Future Research}

New developments in cord blood stem cell research may demonstrate a need for the use of autologous or close-relative use of long-term cord blood in a private banking system. A smaller but no less important need for family-directed cord blood banks continues to be demonstrated for families with known malignancies or congenital diseases (eg, children with severe primary immunodeficiencies and hemoglobinopathies). These special cord blood banks are frequently located at university teaching hospitals. Private or autologous cord blood banking may be considered for experimental stem cell regenerative research, in which stem cell transplants are used to attempt to restore nonfunctioning or diseased nonhematologic tissue (eg, central nervous system or heart muscle). However, local institutional review board-approved protocols are necessary in addition to Food and Drug Administration approval, if applicable. Moreover, parents would need to sign the institutional review board-approved informed consent document if private banking is used for this purpose.

\section{RECOMMENDATIONS}

1. Public cord blood banking is the preferred method of collecting, processing, and using cord blood cells for use in transplantation in infants and children with fatal diseases, such as malignancies, blood disorders, immune deficiencies, and metabolic disorders. There is a more limited role of private cord blood banking with families with a known fatal illness that can be rescued by a healthy cord blood transplant within the family;
2. It is important that the concepts of autologous and allogeneic use of cord blood units be explained to parents by physicians and medical staff to enable expectant parents to make informed choices regarding where they should deposit their infant's cord blood and whether to restrict the blood for the infant's or family's use or release it to the public for any child in need of stem cell transplantation;

3. Physicians need to convey accurate information about the potential benefits and limitations of allogeneic and autologous cord blood banking and transplantation to parents, including that autologous cord blood would not be used as a stem cell source if the donor developed leukemia later in life. It is important for parents to be aware that at this time, there are no scientific data to support the claim that autologous cord blood is a tissue source proven to be of value for regenerative medical purposes, although researchers are examining this possibility;

4. It is expected that physicians and designated medical staff obtain specific permission for maintaining demographic medical information and that the potential risks of breaches of confidentiality be disclosed to parents. Specific efforts need to be made to recruit underserved ethnic minorities for cord blood donations to enlarge the public cord blood repositories and better serve these patient populations. Before the onset of active labor, written permission needs to be obtained from parents to collect the cord blood for banking purposes. If the cord blood bank is conducting therapeutic human research involving cord blood, review and approval of the recruitment strategies and parental consent forms by the institutional review board are necessary;

5. The AAP advocates for regulatory agencies (eg, the Food and Drug Administration, the Federal Trade Commission, and state equivalents of these federal agencies) to have an active role in providing oversight of the cord blood program. It is important that all cord blood banking programs comply with FACT or equivalent accreditation standards; and

6. Physicians or other professionals who recruit pregnant women and their families for for-profit placental cord blood stem cell banking need to disclose any financial interest or other potential conflict of interest they have relative to the procedure to their patients. Similarly, professionals affiliated with institutions or organizations that promote for-profit placental blood stem cell banking need to make annual financial-disclosure and potential-conflicts-of-interest statements to an appropriate institutional review committee that possesses oversight authority.

\section{ACKNOWLEDGMENTS}

We thank Ms Janice Hopkins and Ms Carolyn Jackson for their assistance in preparing this policy statement.

\section{LEAD AUTHORS}

William T. Shearer, MD, PhD, FAAP

Bertram H. Lubin, MD, FAAP

Mitchell S. Cairo, MD, FAAP

Luigi D. Notarangelo, MD

\section{SECTION ON HEMATOLOGY/ONCOLOGY EXECUTIVE COMMITTEE, 2015-2016}

Jeffrey Hord, MD, FAAP, Chairperson
Gary Crouch, MD, FAAP
Gregory Hale, MD, FAAP
James Harper, MD, FAAP
Jeffrey Lipton, MD, FAAP
Zora Rogers, MD, FAAP

Jeffrey Hord, MD, FAAP, Chairperson

Gary Crouch, MD, FAAP

Gregory Hale, MD, FAAP

James Harper, MD, FAAP

Zora Rogers, MD, FAAP 
Eric Werner, MD, FAAP, Immediate Past Chairperson

\section{STAFF}

Suzanne Kirkwood, MS

\section{SECTION ON ALLERGY AND IMMUNOLOGY EXECUTIVE COMMITTEE, 2015-2016}

Elizabeth C. Matsui, MD, FAAP, Chairperson

Stuart L. Abramson, MD, PhD, FAAP

Chitra Dinakar, MD, FAAP

Anne-Marie Irani, MD, FAAP

Todd A. Mahr, MD, Immediate Past Chairperson
Jennifer S. Kim, MD, FAAP

Michael Pistiner, MD, FAAP

Julie Wang, MD, FAAP

\section{ADDITIONAL CONTRIBUTORS}

Thomas A. Fleisher, MD, FAAP, past member Scott H. Sicherer, MD, FAAP, past member Paul V. Williams, MD, FAAP, liaison to the American Academy of Allergy, Asthma, and Immunology

\section{STAFF}

Debra Burrowes, MHA

\section{ABBREVIATIONS}

AAP: American Academy of Pediatrics

FACT: Foundation for the Accreditation of Cellular Therapy

HSCT: hematopoietic stem cell transplant

SCID: severe combined immunodeficiency disease

Address correspondence to William T. Shearer, MD, PhD, FAAP. E-mail: wtsheare@texaschildrenshospital.org

PEDIATRICS (ISSN Numbers: Print, 0031-4005; Online, 1098-4275)

Copyright (C) 2017 by the American Academy of Pediatrics

FINANCIAL DISCLOSURE: Dr Notarangelo is supported by the Intramural Research Program of the National Institute of Allergy and Infectious Diseases, National Institutes of Health; and Drs Shearer, Lubin, and Cairo have indicated they have no financial relationships relevant to this article to disclose.

FUNDING: No external funding.

POTENTIAL CONFLICT OF INTEREST: Dr Notarangelo has had a consulting relationship with Sigma-Tau; this relationship is not currently active; and Drs Shearer, Lubin, and Cairo have indicated they have no potential conflicts of interest to disclose.

\section{REFERENCES}

1. Oran B, Shpall E. Umbilical cord blood transplantation: a maturing technology. Hematology Am Soc Hematol Educ Program. 2012;2012:215-222

2. American Academy of Pediatrics Section on Hematology/0ncology; American Academy of Pediatrics Section on Allergy/Immunology; Lubin BH, Shearer WT. Cord blood banking for potential future transplantation. Pediatrics. 2007;119(1):165-170

3. Delaney C, Bollard CM, Shpall EJ. Cord blood graft engineering. Biol Blood Marrow Transplant. 2013;19(suppl 1):S74-S78

4. Ballen KK, Gluckman E, Broxmeyer HE. Umbilical cord blood transplantation: the first 25 years and beyond. Blood. 2013;122(4):491-498

5. Yoder MC. Cord blood banking and transplantation: advances and controversies. Curr Opin Pediatr. 2014;26(2):163-168

6. Gluckman E, Ruggeri A, Rocha V, et al. Eurocord, NetCord, World Marrow Donor Association, and National Marrow Donor Program. Familydirected umbilical cord blood banking. Haematologica. 2011;96(11): 1700-1707
7. Cairo MS, Rocha V, Gluckman E, Hale G. Wagner J. Alternative allogenic donor sources for transplantation for childhood diseases: unrelated cord blood and haploidentical family donors [published correction appears in Biol Blood Marrow Transplant. 2008;14(11):1317-1318]. Biol Blood Marrow Transplant. 2008;14(1, suppl 1):44-53

8. Kurtzberg J. A history of cord blood banking and transplantation. Stem Cells Trans/ Med. 2017;6(5):1309-1311

9. Cutler C, Ballen KK. Improving outcomes in umbilical cord blood transplantation: state of the art. Blood Rev. 2012;26(6):241-246

10. Barker JN, Scaradavou A, Stevens CE. Combined effect of total nucleated cell dose and HLA match on transplantation outcome in 1061 cord blood recipients with hematologic malignancies. Blood. 2010;115(9):1843-1849

11. Fernandes JF, Rocha V, Labopin M, et al; Eurocord and Inborn Errors Working Party of European Group for Blood and Marrow Transplantation. Transplantation in patients with SCID: mismatched related stem cells or unrelated cord blood? Blood. 2012;119(12):2949-2955
12. Cavazzana-Calvo M, André-Schmutz I, Fischer A. Haematopoietic stem cell transplantation for SCID patients: Where do we stand? Br J Haematol. 2013;160(2):146-152

13. Parikh S, Szabolcs P. Reduced-intensity conditioning (RIC) in children with nonmalignant disorders (NMD) undergoing unrelated donor umbilical cord blood transplantation (UCBT). Biol Blood Marrow Transplant. 2012;18(suppl 1):S53-S55

14. Geyer MB, Jacobson JS, Freedman $J$, et al. A comparison of immune reconstitution and graft-versus-host disease following myeloablative conditioning versus reduced toxicity conditioning and umbilical cord blood transplantation in paediatric recipients. Br J Haematol. 2011;155(2):218-234

15. Horwitz ME, Chao NJ, Rizzieri DA, et al Umbilical cord blood expansion with nicotinamide provides long-term multilineage engraftment. J Clin Invest 2014;124(7):3121-3128

16. Herr AL, Kabbara N, Bonfim CM, et al. Long-term follow-up and factors influencing outcomes after related HLA-identical cord blood transplantation for patients 
with malignancies: an analysis on behalf of Eurocord-EBMT. Blood. 2010;116(11):1849-1856

17. Broxmeyer HE. Enhancing engraftment of cord blood cells via insight into the biology of stem/progenitor cell function. Ann N Y Acad Sci. 2012;1266(1):151-160

18. Kwan A, Abraham RS, Currier R, et al. Newborn screening for severe combined immunodeficiency in 11 screening programs in the United States. JAMA. 2014;312(7):729-738

19. Pai S-Y, Logan B, Griffith LM, et al. Transplant outcomes for severe combined immunodeficiency from 2000-2009. N Engl J Med. 2014;371(5):434-446

20. Moratto D, Giliani S, Bonfim C, et al. Long-term outcome and lineagespecific chimerism in 194 patients with Wiskott-Aldrich syndrome treated by hematopoietic cell transplantation in the period 1980-2009: an international collaborative study. Blood. 2011;118(6):1675-1684

21. Shlush LI, Zandi S, Mitchell A, et al. Identification of preleukaemic haematopoietic stem cells in acute leukaemia. Nature. 2014;506 (7488):328-333

22. Yasuda T, Ueno T, Fukumura $\mathrm{K}$, et al. Leukemic evolution of donor-derived cells harboring IDH2 and DNMT3A mutations after allogeneic stem cell transplantation. Leukemia. 2014;28(2):426-428

23. Cotten CM, Murtha A, Goldberg R, et al. Feasibility of autologous cord blood cells for infants with hypoxicischemic encephalopathy. J Pediatr. 2014;164(5):973-979

24. Petrini C. Ethical issues in umbilical cord blood banking: a comparative analysis of documents from national and international institutions. Transfusion. 2013;53(4):902-910

25. Armson A; Maternal/Fetal Medicine Committee, Society of Obstetricians and Gynaecologists of Canada. Umbilical cord blood banking: implications for perinatal care providers. J Obstet Gynaecol Can. 2005;27 (3):263-290

26. World Marrow Donor Association. WMDA policy statement for the utility of autologous or family cord blood unit storage. Approved and adopted by the WMDA board on the 25th of May 2006. Updated 2011. Available at: http://bloodcell.transplant.hrsa.gov/ cord/files/wmdapolicystatement.pdf. Accessed December 6, 2016

27. American College of Obstetricians and Gynecologists, Committee on Obstetric Practice, Committee on Genetics. Umbilical cord blood banking. ACOG Opinion No. 399. February 2008 (Replaces No. 183, April 1997). Obstet Gynecol. 2008;111 (2, pt 1):475-477

28. Assemblée Nationale de la République Française; Sénat de la République Française. Loi no 2011-814 du 7 juillet 2011 relative à la bioéthique. Journal Officiel de la République Française. 2011:157

29. États Généraux de la Bioéthique. Rapport final. 2009. Available at: http:// benoit.urgelli.free.fr/Recherches/ Formation/Consultation-0GM-2009/ RapportFinalEtatsGeneraux2009Extra itCSE.pdf. Accessed September 20, 2017

30. Assemblée Nationale de la République Française. Leonetti J, ed. Rapport d'information fait au nom de la mission d'information sur la révision des lois de bioéthique, $\mathrm{n}^{\circ} 2235$. Tome 1: Rapport. 2010. Available at: www. assembleenationale.fr/13/rap-info/ i2235-t1.asp. Accessed July 11, 2012

31. Assemblée Nationale de la République Française. Leonetti J, ed. Rapport d'information fait au nom de la mission d'information sur la révision des lois de bioéthique, $\mathrm{n}^{\circ} 2235$. Tome 2: Auditions. 2010. Available at: www. assembleenationale.fr/13/rap-info/ i2235-t2.asp. Accessed July 11, 2012

32. Académie Nationale de Médecine., eds. Les cellules souches du cordon et du placenta: de la recherche aux applications thérapeutiques. Rapport adopté le. 2010. Available at: www.academie-medecine.fr/ detailpublication.cfm?idrub $=26 \&$ idligne=1772. Accessed September 20, 2017

33. Collège National des Gynécologues et Obstétriciens Français. Non aux sociétés à but lucratif incitant à la conservation de sang de cordon à visée autologue. 2009. Available at:
www.cngof.asso.fr/D_TELE/com_ press10-12-09.pdf. Accessed July 11, 2012

34. Centro Nazionale Sangue (CNS), Centro Nazionale Trapianti (CNT). Posizione del Centro Nazionale Sangue e del Centro Nazionale Trapianti sull'uso autologo del sangue cordonale. 2010. Available at: www.trapianti.salute.gov it/cnt/comunicato/notacongiunta.pdf. Accessed December 6, 2016

35. Agence de la Biomédecine (République Française). Le don de sang placentaire. Une source irremplaçable de cellules souches pour la greffe allogénique. 2010. Available at: www.agencebiomedecine.fr/IMG/pdf/doc_don_ placentaire-2.pdf. Accessed July 11, 2012

36. Agence de la Biomédecine (République Française). Le don, le prélèvement et la greffe de sang de cordon. 2012. Available at: https://www. agence-biomedecine.fr/Donation-andtransplantation-of?lang=fr. Accessed July 11, 2012

37. Société Française de Greffe de Moelle et de Thérapie Cellulaire (SFGM-TC). Appel à la vigilance sur les sociétés privées incitant à la conservation de sang à visée autologue. Communiqué de presse. Available at: https://www. agence-biomedecine.fr/IMG/pdf/ sfgmtcsangplacentaire81209vdef.pdf. Accessed September 20, 2017

38. Agence de la Biomédecine (République Française). Utilisation thérapeutique du sang de cordon: une clarification s'impose. Communiqué de presse. 2010. Available at: https://www. agence-biomedecine.fr/Communiquesde-presse-2010?lang=fr. Accessed September 20, 2017

39. .Agence de la Biomédecine (République Française). Organisation du don de sang de cordon en France en 2010. 2010. Available at: https://www.agencebiomedecine.fr/IMG/pdf/panoramasang-cordon-janv-2010.pdf. Accessed September 20, 2017

40. Comité Italo-Français pour le bon usage du sang du cordon ombilical. Audition au Parlement Européen sur le don de la solidarité, collection privée et la préservation du sang de cordon ombilical. 2011. Available at: http:// www.adoces.it/wordpress/wp-content/ 
uploads/2011/03/Eurodeputati-

francese.pdf. Accessed July 11, 2012

41. Isasi R, Dalpe G, Knoppers BM. Fostering public cord blood banking and research in Canada. Stem Cells Dev. 2013;22(suppl 1):29-34

42. Stewart CL, Aparicio LC, Kerridge IH. Ethical and legal issues raised by cord blood banking - the challenges of the new bioeconomy. Med J Aust. 2013;199(4):290-292

43. NetCord. Position Statement on Cord Blood for Autologous Use. Arlington Heights, IL: NetCord Newsletter; 2008

44. Guilcher G, Fernandez CV, Joffe S. Are hybrid umbilical cord blood banks really the best of both worlds? J Med Ethics. 2015;41(3):272-275

45. Petrini C. Umbilical cord blood collection, storage and use: ethical issues. Blood Transfus. 2010;8(3):139-148

46. NetCord, Foundation for the Accreditation of Cell Therapy. NetCordFACT international standards for cord blood collection, processing, and release for administration. 4th ed. 2010. Available at: http://stemcellbank org.ua/wp-content/uploads/2013/ 08/INTERNATIONAL-STANDARDS-FORCORD-BLOOD-COLLECTION-BANKING-ANDRELEASE-FOR-ADMINISTRATION-4th Edition.pdf. Accessed December 6, 2016
47. Foundation for the Accreditation of Cell Therapy, Joint Accreditation Committee ISCT-EBMT. FACTJACIE international standards for cellular therapy product collection, processing and administration. 5th ed. 2012. Available at: www.jacie.org/documentcentre/Standards\%205th\%20ed. pdf?attredirects $=0 \& d=1$. Accessed December 6, 2016

48. Boo M, Welte K, Confer D. Accreditation and regulation of cord blood banking. In: Brokmeyer HE, ed. Cord Blood: Biology, Transplantation, Banking, and Regulation. Bethesda, MD: American Association of Blood Banks; 2011:663-672

49. Butler MG, Menitove JE. Umbilical cord blood banking: an update. J Assist Reprod Genet. 2011;28(8):669-676

50. National Cord Blood Program. Available at: http://nationalcordbloodprogram. com. Accessed December 6, 2016

51. Sun J, Allison J, McLaughlin C, et al. Differences in quality between privately and publicly banked umbilical cord blood units: a pilot study of autologous cord blood infusion in children with acquired neurologic disorders. Transfusion. 2010;50(9):1980-1987

52. American College of Obstetricians and Gynecologists. Umbilical cord blood banking. ACOG Committee Opinion No. 399. Obstet Gynecol. 2008;111(2, pt 1):475-477

53. Cord Blood Working Group. Combined private and public banking of cord blood and other related products. Leiden, NL: World Marrow Donor Association; 2012. Available at: www.worldmarrow.org/fileadmin/ committees/cord_blood_working_ group/20120328-CBWG-PPR-Hybrid.pdf. Accessed December 6, 2016

54. Ballen KK, Verter F, Kurtzburg J. Umbilical cord blood donation: public or private? Bone Marrow Transplant. 2015;50(10):1271-1278

55. Lubin BH, Yeaton-Massey A, Lewak N, O'Connor KG. To bank or not to bank cord blood: a national survey of pediatrician counseling practices. In: Annual Meeting of the Pediatric Academic Societies; May 2-5, 2009; Baltimore, MD. Available at: www.aap. org/en-us/professional-resources/ Research/Pages/To-Bank-or-Not-toBank-Cord-Blood-A-National-Survey-ofPediatrician-Counseling-Practices.aspx Accessed December 6, 2016

56. Bhandari R, Lindley A, Bhatla D, et al. Awareness of cord blood collection and the impact on banking. Pediatr Blood Cancer. 2017;64(7):e26412 